\title{
CORRESPONDENCE
}

\section{Future world energy needs}

SIR, - It would have been most instructive if we had been told the composition of the "Conservation Commission" of the World Energy Conference, whose 1978 Report on Energy Requirements between 1985 and 2020 was reviewed in Nature (November 15, page 344). Neither the Commission nor your reviewer appear to have addressed themselves to the possibility of meeting their projected goals. To reach them the Commission says that nuclear generating capacity must be doubled every six years from 1985 . If we suppose that there would be no more than 200 $1000 \mathrm{MWe}$ reactors operating by that date, this growth rate would mean that 12,800 reactors of the same size would have to be built by 2020 . To reach this number the world would have to build a reactor a day from 1985 onwards. Furthermore, since reactors are unlikely to last more than about 35 years, by 2020 , this rate of building would have to increase to two per day unless of course demand miraculously levelled off at this poin in which case it would merely be necessary to go on building a reactor a day for evermore.

The 12,800 reactors to be completed by 2020 AD would, during their lifetimes, need to consume up to 140 million tonnes of uranium metal, which is $10-15$ times the 1979 estimates for the world's stock of uranium costing less than $\$ 30$ a pound to extract.

The UK government has recently given an estimate of $£ 8 \times 10^{8}$ for building a $1000 \mathrm{MWe}$ nuclear plant. 12,800 reactors of this type would therefore cost a total in the region of $£ 10^{13}$ in 1979 values. This and the fact that at present in the US it takes about 10 years between design and commissioning of a reactor (and reactors become steadily more complex in an effort to meet ever-stricter safety requirements) appear to indicate that the world's attitude to energy consumption will have to change radically within a few years from now.

In assessing energy "demands" one must remember that a $1974 \mathrm{UN}$ forecast was that average energy "demand" in the developed countries up to $2020 \mathrm{AD}$ would rise thirteen times as fast as population, whereas it was expected to fall in the developing ones. Projections of energy demand are therefore merely estimates of how much energy people will be willing and able to buy: they have nothing to do with opinions about what distribution of energy consumption would be socially or morally desirable. Perhaps we should start asking ourselves such questions now?

Yours faithfully,

R. B. TEMPLE Physical Chemistry Department, University of Sydney, Australia

\section{Biotechnology report}

SIR, - I should be grateful if I might make it clear to your readers that the Biotechnology Report partly published by you (24 January, page 324) was not "made available to Nature" by the Working Party, who were unaware that you had obtained an early draft until two days before its publication. It was an uncorrected, tentative draft, sent to our three sponsors

(ACARD, ABRC, and the Royal Society), and to many of those who gave evidence to us, in November. Their advice led to significant alterations, only completed on 21 January What I hope will be the final draft has now been sent to the sponsors for approval of publication.

Yours faithfully,

Wilmslow, Cheshire, UK

\section{Short-term research contracts}

SIR, - It is indeed heartening to read your valuable and informed coverage of the problems of experienced and accomplished scientists stranded and unemployed in their thirties and forties. It is equally disheartening that Nature is almost completely alone, both in the specialist and the national press, in drawing attention to the problem and its magnitude.

Why is everyone apparently so complacent? Are research directors and professors alike so committed to the exploitation of cheap and expendable labour that they see no need to speak out against a system whose iniquities they have been fortunate enough to escape and whose benefits they shamelessly enjoy? Why do we hear nothing from the heads of research councils and grant-giving agencies? It may be argued that the present situation has developed of its own accord. Does this mean that nobody should now begin to set matters right? Where does responsibility for perpetuation lie?

I issue a challenge, to the head of any research council or funding organisation, to defend the present system of short-term contracts in scientific research. I challenge him to defend the practice of signing away rights in common law as a prerequisite for the acceptance of such contracts. I challenge him to justify the expenditure of public money on the training and usage of men and women drawn from the most talented sections of the community, to be tossed into the dole queue before their full potential is realised. Yours faithfully,

ROBERT JONES

Am Steinberg 67, Heidelberg, Germany

\section{Pheasants and spies}

SIR, - Having just returned from Kathmandu, Nepal, where a highly successful International Pheasant Symposium was held from 21-24 November, I was horrified to read your story headline 'India's wildlife projects under spy cloud' (29 November, page 435). In this story, under a cartoon depicting Kashmir pheasant beaters, you report that "Foreign collaborators might use the [World Pheasant Association's] pheasant project [for the reintroduction of the Cheer pheasant] as a camouflage for spying in the sensitive borderland",

Had you checked with the World Pheasant Association you would have discovered that the "foreign collaborators" for this project confine themselves to despatching batches of Cheer pheasant eggs from Heathrow to Delhi, where they are met by Indians, hatched by Indians and reared by Indians with the full knowledge and support of the state governments concerned; clearly they do not share your correspondent's fear.

To set up the project I have myself visited the Wildlife Departments and other officials in Lucknow (Uttar Pradesh), Simla (Himachal Pradesh) and Srinager (Kashmir), all leading tourist centres and none of them on the 'sensitive borderland'. The publication of unmitigated nonsense like this can do the work of recognised charitable conservation organisations like the World Pheasant Association and its objectives nothing but harm.

Finally, the World Pheasant Association received from the Chief Minister of Jammu and Kashmir an invitation to hold the Second International Pheasant Symposium in

Kashmir, (an invitation that is being accepted). Hardly the action of a government concerned with spies infiltrating its territory. Yours faithfully

K.C.R. HowMAN World Pheasant Association, Suffolk, UK
Standardisation of

\section{research citations}

SIR, - Three groups of life science editors have tried to achieve the standardisation of reference citation for which P.C. Reid argues so cogently (17 January, page 242).

First, in 1973 the biochemists (IUB-CEBJ) ${ }^{1}$ published a reference list style suitable for journals adopting either the 'Harvard' system (names and dates) or numbers for citations in the text:

Abel, B.C., Cain, A.D., Adam, E. \& Eve, A. (1976) Tree J., 12, 90-99

Second in 1977 ELSE (European Life Science Editors' Association) and the Ciba Foundation organised a workshop on references and produced a set of suggestions ${ }^{2}$ for a style that is also suitable for either names/dates or numbers in the text:

Abel BC, Cain AD, Adam E, Eve A 1976

Bark thickness in apple trees. Tree Journal 12:90-99 (or Tree J 12:90-99)

Third in 1978 the International Steering Committee of Medical Editors proposed what is now known as the Vancouver style ${ }^{3}$, suitable only for citation by numbers:

Abel BC, Cain AD, Adam E, Eve A. Bark thickness in apple trees. Tree J 1976;12:90-99.

The main differences between the first and second systems lie in the punctuation, the typefaces, and whether article titles are included or omitted. The main differences between the second and third systems lie in the way references are cited in the text and in the punctuation and position of the date in the reference list. All three systems recommend that the 'International List' (ISO 833-1974; BS 4148 Part 1; 1970 and Part 2:1975) should be used for abbreviating journal titles, in preference to the World List.

The ELSE-Ciba Foundation system suggests that journal titles might be either unabbreviated or abbreviated, provided that each reference list is self-consistent on this point. A later suggestion is that editors and publishers should allow both names/dates and numbers in the same journal or book, provided that each article or chapter follows one style consistently. Since the American National Standard (ANSI Z39.29-1977) and the draft International Standard (DIS 690) on bibliographic references both permit flexibility in the position of the various elements, including the date, in reference lists it would be a great step forward if the third system became more flexible on this, so allowing names/dates to be used in the text. The second and third systems would then be even more alike than they already are, and the work of authors, typists and typesetters would be enormously simplified. (Copies of the ELSECiba Foundation system are available in either a full or an abbreviated form from the editorial department of the Ciba Foundation, 41 Portland Place, London W1N 4BN, to anyone enclosing a self-addressed adhesive label with their request.) Yours faithfully, MAEVE O'CONNOR

The Ciba Foundation, London, UK

\footnotetext{
IUB-CEBJ. Eur. J. Biochem. 37, $201-202$ (1973). (And elsewhere.

O'Connor, M. Editing Scientific Books and Journals, p 176-185 (Pitman Medical, Tunbridge Wells, 1978). (And elsewhere.)

International Steering Committee of Medical Editors. Br med. J. 1, 532-535 (1979). (And elsewhere.)
} 